\title{
Mitigating post-oil sustainability challenges in a topographically framed transit-oriented city
}

\author{
Tijana TUFEK-MEMISEVIC, Ph.D. Eng. Arch., Candarc, LLC, USA \\ Zina RUZDIC, MSc. Arch., Research Fellow at MIT, Bosnia \& Herzegovina
}

\begin{abstract}
A distinct environmental setting of the naturally elongated city of Sarajevo, Bosnia and Herzegovina stimulated its historical development in a constant transit-oriented manner despite its frequent and diverse regime shifts, planning practices and periods of war destruction. Topographically conditioned natural processes along with anthropogenic factors contributed to increasing challenges to urban sustainability. With Sarajevo in the top ranks, the country's alarming level of air pollution was rated number one in Europe in 2019 with an annual average of 40,9 $\mathrm{\mu g} / \mathrm{m} 3$ of PM2.5 (IQAir, 2020). The emergence of high-rise development without proper long-term planning strategies largely contributes to smog retention as a recent study on ventilation corridors in the city has shown (EBRD, 2019). As in many Southeast European cities over the last few decades, Sarajevo is dealing with an urban sprawl generated by the development of informal settlements (Tsenkova, 2012). These represent the dominant developments on surrounding hillsides around the city, accessible mainly by vehicle transportation, creating an aggravating factor on infrastructure, air quality and future development. Current practice in mitigating these challenges are scarce and often obstructed by adverse political agendas. The border of two uncooperative and structurally different governing Entities stretches alongside the city and hinders a unified long term regulation plan. The main research approach of this paper is based on grounded theory and case studies of cities with similar elevation variations. The paper establishes two main challenges to a sustainable urban development for a valley-based city in air quality and transportation. It elucidates sustainable urban planning opportunities in an oil-depleted future of Sarajevo while dealing with the given circumstances of urban disengagement and infrastructural pressure of the peripheral hillside developments and the urgent vertical growth restrictions in the valley, providing conceptual solutions for urban integration of the largely informal settlements through cable propelled modes of transportation and heat source reevaluation.
\end{abstract}

\section{Keywords}

Valley, air pollution, hillside developments, cable propelled transit

\section{Introduction}

Urban areas around the world experience growing pressure on a sustainable and resilient existence and development. In addition to rapid urbanization, climate change and natural disasters aggravated by anthropogenic activity, the recent Covid-19 pandemic drew attention to the importance of health resilience for the future of cities. One of the most significant environmental health hazards is air pollution with $90 \%$ of global population breathing air that exceeds WHO annual PM.25 threshold of $10 \mu \mathrm{g} / \mathrm{m} 3$ (IQAir, 2020). Communities exposed to long-term particle pollution are also at higher risk of severe or deadly infections caused by the virus.

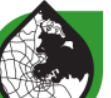


Development of long-term plans to mitigate post-oil sustainability challenges is a global as well as place-specific effort. The aim of this paper is to highlight aggravating conditions in mitigating such challenges through air quality control, transportation and planning policy specific to urban areas with certain topographic features, as is the case of Sarajevo.

Sarajevo is the capital city of Bosnia and Herzegovina, located on the Balkan Peninsula in Southeast Europe. In 2019 the region was ranked highest in PM2.5 pollution in Europe and BIH number one most polluted country with an annual average of $34,6 \mu \mathrm{g} / \mathrm{m} 3$ (IQAir, 2020). Although geographically being part of Europe, Bosnia and Herzegovina is not part of the EU. Together with several neighboring countries it is neither a developed nor developing country. It is classified by WESP as a country with transitioning economy. The way politics and planning policy has been conducted since the dissolution of Yugoslavia and the war of 1992-1995, impacted the prolongation of this status. As such, the country currently does not succumb to the strict environmental policies of the EU which has significant implications on the environmental challenges that it is facing.

Sarajevo has a distinct topography which significantly influenced the city's development throughout history. It is situated in a narrow valley which conditioned urban spread onto the adjacent hillsides. Traffic in the city is strongly oriented towards a main artery along the valley and Miljacka river basin. Essentially, Sarajevo is a naturally elongated mostly transit-oriented city with a complex and diverse historic background. Frequent shifts in regime and war destruction prevented a planned large-scale city development. One of the consequences of the unstable socioeconomic conditions is the construction of illegal settlements on the slopes and landslides. These settlements are predominantly residential. They are poorly connected to the main traffic system, create pressure on the cities infrastructure system, services and use heating sources that contribute significantly to air pollution.

The main research methodology of this paper is grounded theory based on data collection and analysis in addition to case studies of urban areas with similar topographic features. The paper provides conceptual solutions mitigating the effects of air pollution through a revision of heating sources, traffic interventions and commuter options in an urban area that largely depends on fossil fuels. The solutions also aim to strengthen the urban integration of hillsides with largely informal settlements and possible recreational areas. The purpose of it is to elucidate sustainable urban planning opportunities in an oil-depleted future of the city by adhering to the principles of transit-oriented planning consistent with Sarajevo's historic development while also dealing with the existing environmental circumstances, urgent vertical growth restrictions in the valley and urban disengagement of the hillside developments.

\section{Post-oil challenges to cities in valleys}

\subsection{Air quality}

Environmental conditions of most cities around the world are inevitably influenced by less or more significant elevation variations in their vicinity. This influence is particularly important for cities that are based in valleys because they experience a type of Advectional temperature inversion called the Intermontane Valley inversion. It usually happens during cold season when a layer of warm air traps the denser cold air descended from adjacent mountains. However, when mixed with particles from burned fossil fuels the polluted air cannot escape and disperse. This condition can last for days significantly increasing the health risk of inhabitants. What can be influenced though, is the emission of pollutants. Sarajevo is one of these cities as well as Santiago, Chile which ranks as one of the most polluted cities in Latin America. Chile's cold season is opposite to Sarajevo's and lasts from May to August. To address the issue of air pollution the government of Chile launched a program to replace old firewood heaters with more energy-efficient ones which resulted in a reduction of emissions.

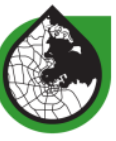


Australia and North America on the other hand are regions with lowest overall pollution levels in the world due to successfully implemented emission controls across numerous industries. There are still cities that exceed the WHO threshold, though. Salt Lake City in Utah experiences higher pollution intervals during winter season due to valley temperature inversion. Since Central and South Asia is the most populated region in the world with only $0.7 \%$ cities that meet the $10 \mu \mathrm{g} / \mathrm{m} 3 \mathrm{WHO}$ target, the region has been evaluated as too broad to be included in this particular study.

Cities in valleys

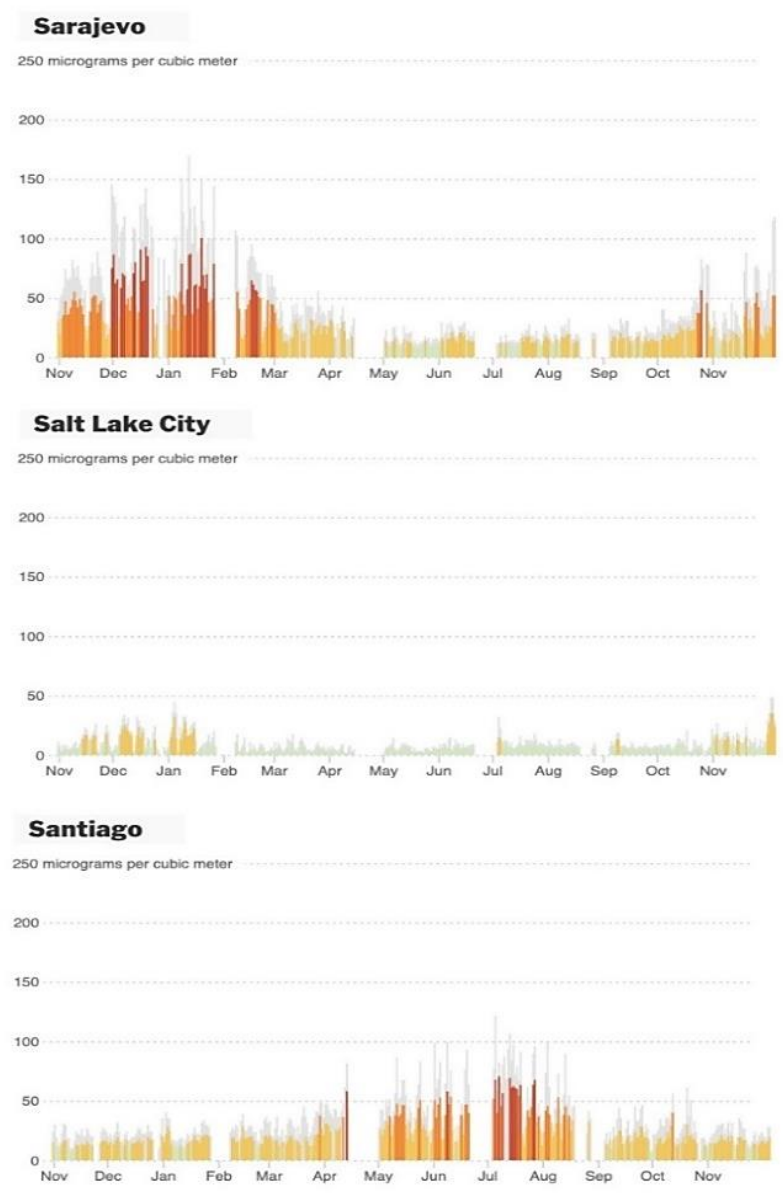

Cities with modest elevation changes
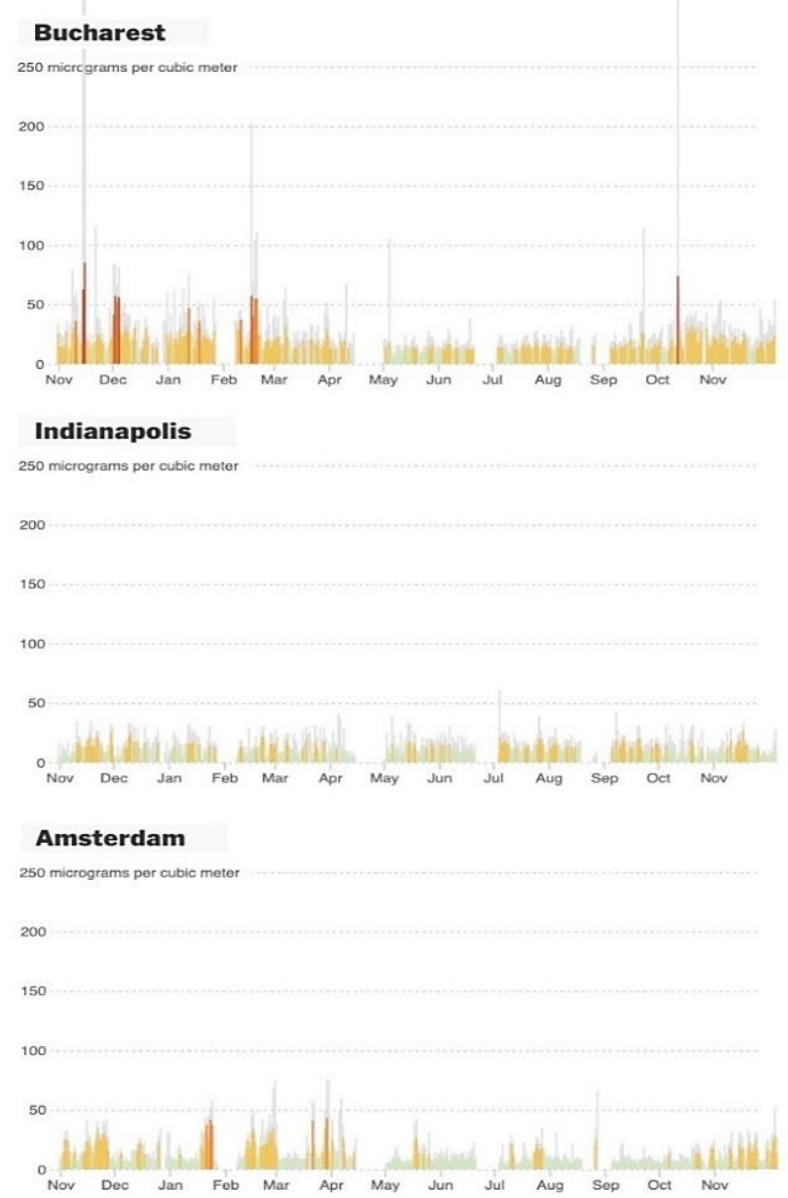

Figure 1: Comparison of a one-year seasonal PM2.5 pollution between cities with and without elevation changes Source: charts derived from interactive graph published by NY Times based on data from Berkley Earth

In the bar chart comparison of air pollution presented (Figure 1) cities situated in valleys are compared to cities with modest elevation changes in $80 \mathrm{~km}$ vicinity over the period of one year from November 2019-November 2020. Cities in valleys exhibit an increase in pollution pattern during cold season compared to cities in flatter areas. Other cities in vicinity of mountains with different types of inversions and seasonal pollution as well as parameters like size of urban area, population density etc. are purposefully neglected for the sake of exhibiting the effects of Valley inversion on prolongation of higher-level seasonal pollution which is detrimental to human health. 
During the ongoing pandemic, as some cities had to go under lockdown for a period of time, and particularly due to decline in motor vehicle transport, a worldwide decrease in air pollution has been noted. In order to follow the WHO safety guidelines of physical distancing and social solidarity we stepped off the narrow sidewalks and began to rethink the use and design of streets. Many cities closed their streets partially or fully for vehicles and opened them up for pedestrian use and cycling. A creativity in resilience is exhibited through alternative use of public spaces, like transformation of parking lots into parklets, open street dinning, outdoor education, play and recreation, while supporting local businesses and helping the economy. This moment presents an unprecedented opportunity to observe and test the possibility of permanently closing parts of cities to individual motor traffic.

\subsection{Trasnportation}

Apart from air quality conditions another challenge to sustainable urban development for cities with significant elevation variations is a lack of transportation options. If not regulated hillside developments are often detached or isolated from the rest of the city and generally rely on vehicular mode of transportation producing exhaust gases and contributing to air pollution. People living in informal detached settlements are subject to social inequality and higher crime rates. The future of transportation in sustainable post-oil cities relies on seamless connection of multimodal transit and use of environmentally friendly technology. A successful but currently underused option for urban areas with elevation variations is both top and bottom supported cable propelled transit.

Medellin, Colombia, situated in the Aburra Valley, set a precedent in using urban gondolas for commuter transit in 2004. The cities hillsides were covered by low-income settlements with high crime rate where local government had little control or presence. The effort of city officials was to socially integrate these areas, improve housing, environment and public spaces by establishing innovative connection, increase mobility and build new public facilities, infrastructure and parks. Medellin's Metrocable system is continuously expanding. It is considered one of the most successful examples of city transformation and became a model for many cities that have built cable propelled transit or consider building one. In 2007 the city of Caracas, Venezuela located in a narrow mountain valley started with the construction of a gondola system for public transport to connect its poorer neighborhoods as well. The city's Metrocable line is extraordinary because it is the first cable line system that implemented a 90-degree turn. (Alshalalfah, B. et al, 2014). In 2006 Portland, OR, another valley city, opened a different type of cable propelled transit called an aerial tram. Contrary to the gondola system comprised of multiple smaller cabins, the aerial tram has only two opposite going cabins that are larger and less frequent.

The aspiration to use cable propelled transit is not limited to cities with hillsides only. Paris is planning the Televal gondola in 2021, and cities across the USA like Albany (NY), Austin (TX), Washington DC and Boston (MA) are considering gondola systems too. Although they are not cities with challenging topography, the idea is to provide a direct, novel and less expensive (than subways, monorails or trains) connection between city areas or fly over gridlocked traffic with little public commuter options. A less successful example is the Emirates Air Line in London which was built for the Summer Olympics 2012. The system experienced a similar fate as many Olympic structures that have not been successfully integrated into the city infrastructure to serve residents rather than tourists only.

Funiculars are a form of bottom supported cable propelled transit to be considered for more than just attraction and recreation, but actual daily commute as well. Additionally, Medellin and Hong Kong have systems of outdoor escalators in inclined areas. However, in Medellin they have not significantly influenced the residents' movement patterns (Reimerink, L. 2017). 


\section{Post-oil sustainability challenges in Sarajevo}
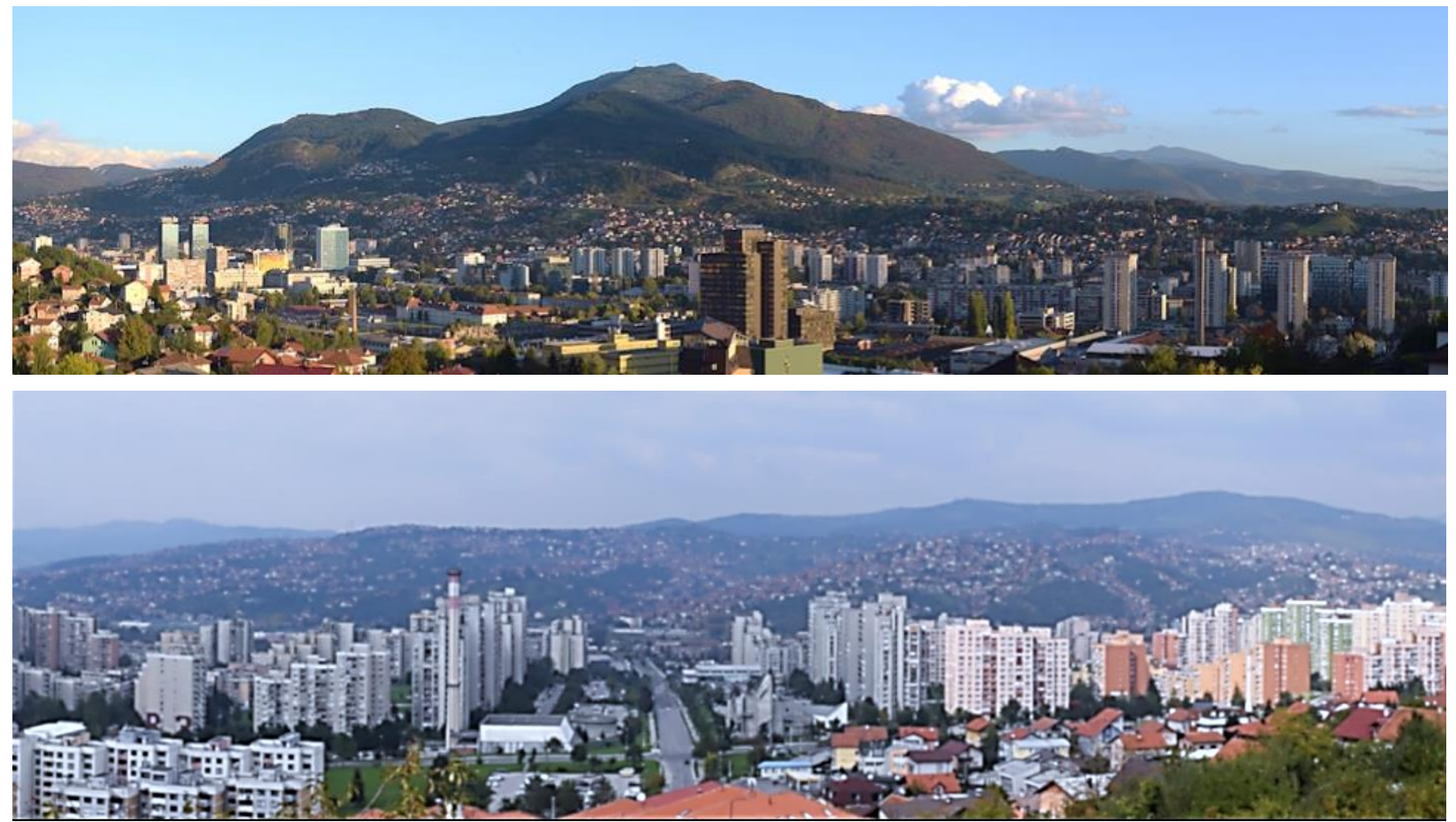

Figure 2: a) Sarajevo valley with mount Trebevic b) distinction between hillside and valley developments Source: Author

Together with adjacent satellite settlements Sarajevo is part of an administrative zone called Canton Sarajevo. Urban development in the valley is public, commercial and residential while the hillsides are predominantly occupied by individual housing, many of which were built without regulation or permit, by semi-professional workers and often under the risk of landslides. The urbanization process of these informal settlements began during the Socialist period as a result of demographic changes, intensified in the post-war decades and continues today on. After the war in 1992-1995 the urban area was administratively divided into two separately regulated governing entities, with the larger part being in the Federation of $\mathrm{BiH}$ and smaller in Republic of Srpska. The Inter Entity boundary line runs directly through part of the city, the settlement of Dobrinja. Although a clear physical boundary doesn't exist, there are opposing collective identities neglecting the presence of the counterpart (Bassi, E. 2015). As a result, there is no unified planning policy or strategy on a larger-urban scale that would encompass the whole urban area of Sarajevo for the foreseeable future. The city's ability to manage land use is affected by the existing informal settlements. In 2006 the governing bodies issued regulations that would allow for the legalization of illegally constructed dwellings. The problem with informal settlements is not unique to $\mathrm{BiH}$. Neighboring countries like Croatia, Serbia, Montenegro and Albania have such settlements as well and applied the legalization strategy in dealing with them (Tsenkova, 2012).

Sarajevo's urban development is primarily conditioned by its topographic setting. The city lies at a 509m elevation in a narrow valley strip among Dinaric mountains Trebevic $(1627 \mathrm{~m})$, Jahorina $(1916 \mathrm{~m})$, Bjelasnica $(2067 \mathrm{~m})$, Igman $(1502 \mathrm{~m})$ and more. The valley is funnel-shaped and narrowest in the northeast, where most of the urban development originated, and spreads southwest to a vast field called Sarajevsko Polje defined by fertile areas and water-protection zones. The narrow shape conditioned a polycentric type of urban development oriented towards the main transportation artery along the basin of river Mijacka (Figure 3). The geomorphology of the area highly affects the climate in the city. Valley temperature inversions are common, 
particularly during cold season when wind intensity and natural ventilation are reduced. Together with anthropogenic activity a layer of smog and fog caps the city which often lasts for an extended period of days. As the cooler night wind drain down the hills (Figure 4b), particularly down mountain Trebevic in the southeast narrow part of the valley (Figure 3: sections 1,2,3) the warmer air rises above trapping pollutants underneath. A heat island is formed in the Eastern part and polluted air is pushed further down the valley by morning winds. High-rise residential buildings (Figure $2 \mathrm{~b}$ ) in the southwestern parts of the valley influenced the natural process of self-purification of the valley.

Topography with section view and annotation (1-7 from East to West)
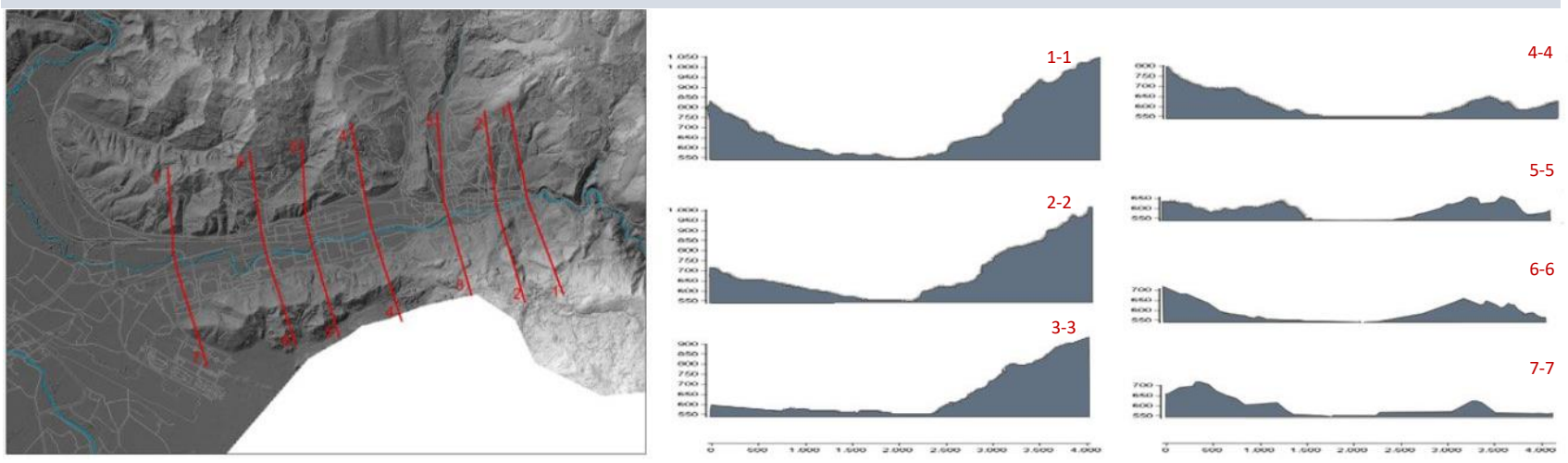

Figure 3: Sections cuts through the valley on a $4 \mathrm{~km}$ width displaying different elevation changes and spread of the valley Source: Map created based on Esri ArcGIS model and sections through extraction of topographic data
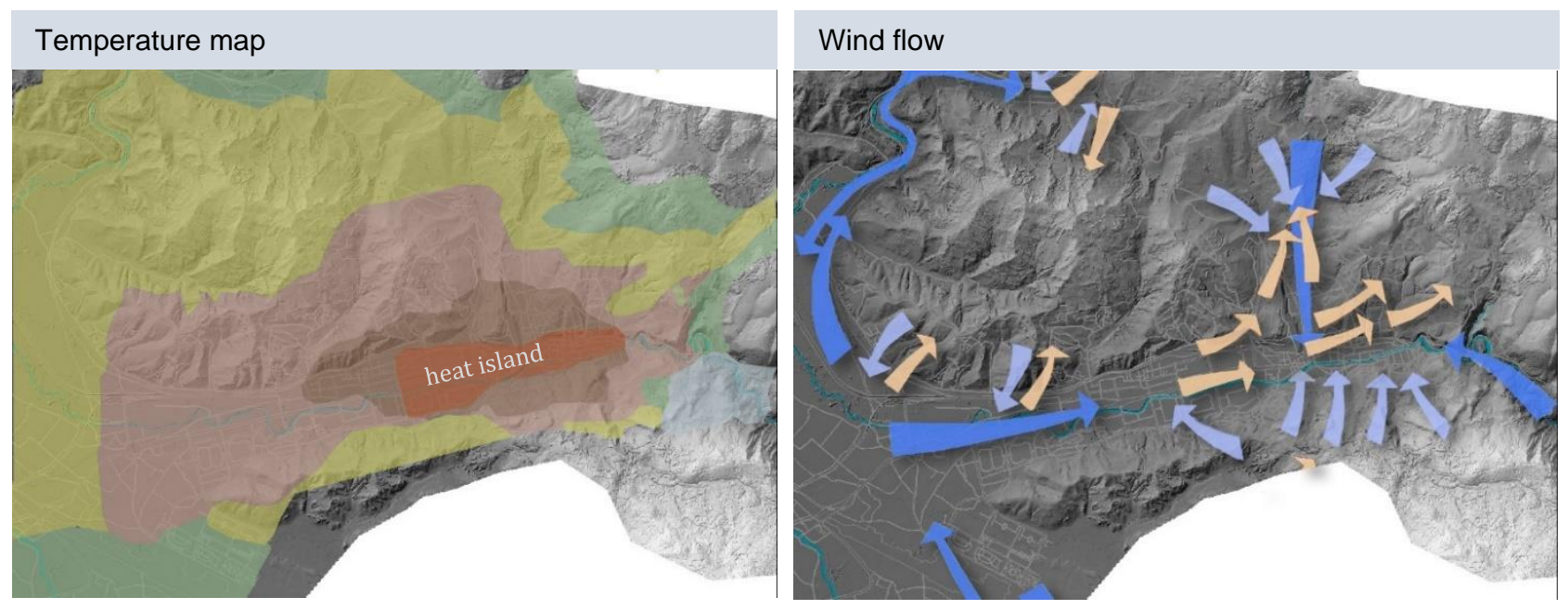

Figure 4: Aerial maps displaying a)temperature differences and b) wind flow in the valley Source: Maps created based on Esri ArcGIS model with overlaying data derived from CS Planning Institue's comprehensive map of "Natural sources and conditions" 


\subsection{Air quality}

As previously underlined Sarajevo ranks among the topmost polluted cities in Europe. The share of deaths caused by air pollution in the BiH exceeds most countries in Europe. However, it is certainly not the only city in $\mathrm{BiH}$ with the same problem. A steel company in Zenica and coal-fired power plants in Kakanj and Tuzla produce the largest amount of air pollution in the country. If $\mathrm{BiH}$ became part of EU these heavy industry facilities would have to obey to more strict environmental regulations.
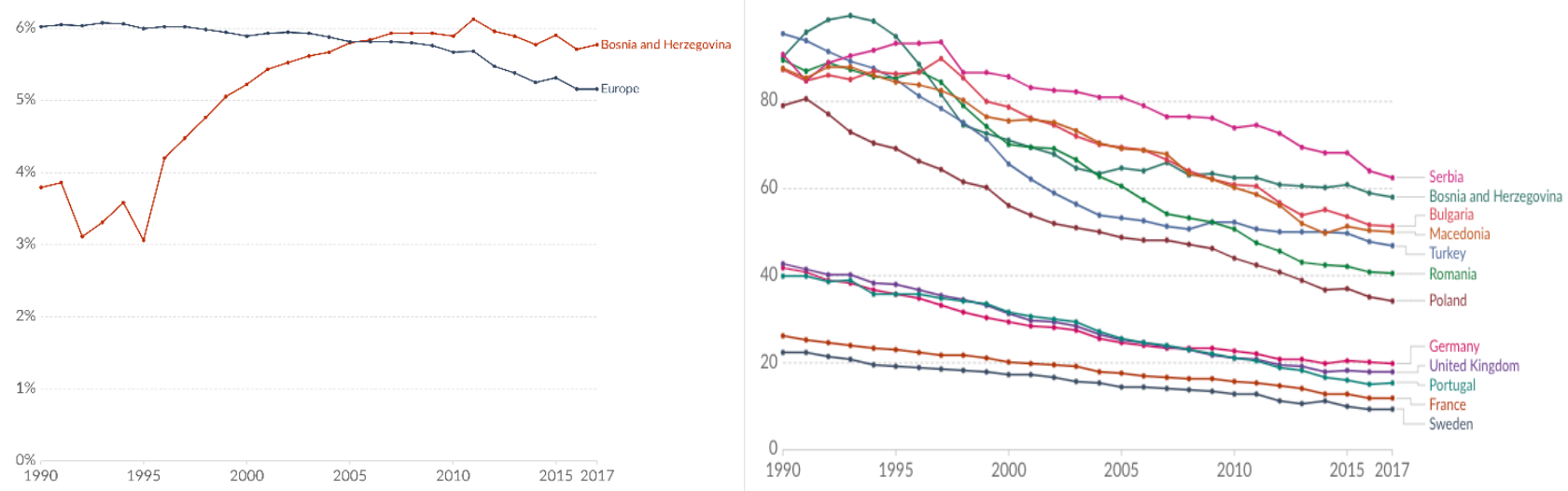

Figure 5: a) Share of deaths from outdoor air pollution in BiH compared to average in Europe b) and share of death compared to several other countries in Europe the period between 1990 to 2017 Source: Our World in Data

The main causes of air pollution in Sarajevo (Figure 6b) are heating sources from residential, public sector, industry and traffic (Ceteor, 2013). There are three main systems of heating in the city. The District Heating System (DHS) which primarily runs on natural gas, central boiler rooms and individual stoves that use different heat sources. In the overall energy consumption in Sarajevo Canton gas takes up 53.2\%, followed by firewood with $17.5 \%$, coal lignite, brown coal $7.7 \%$, electricity $6.0 \%$, fuel oil $1.6 \%$ and pellets/briquettes $0.95 \%$. (UNDP, 2019).

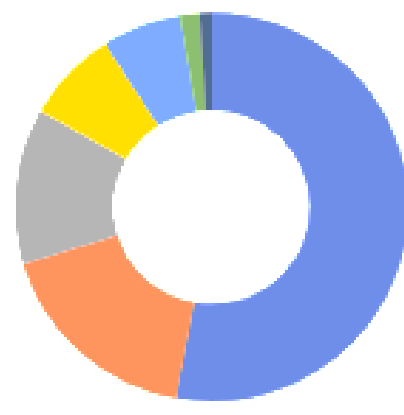

Gas $53.2 \%$

Firewood $17.5 \%$

Coal lignite $13.05 \%$

Brown coal 7.7\%,

Electricity $6.0 \%$

Fuel oil $1.6 \%$

Pellets/briquettes $0.95 \%$

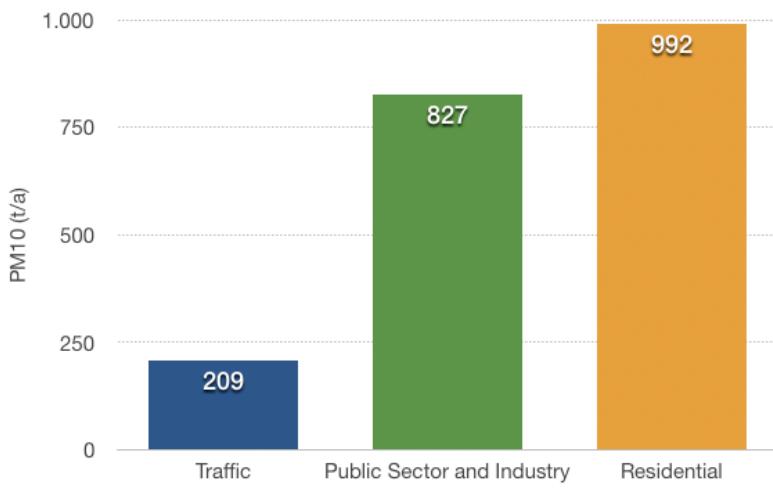

Figure 6: a) chart with heating source distribution in Canton Sarajevo based on data from UNDP Feasibility Study 2019 b) PM10 particle distribution across sectors based on Action plan by CETEOR 2013 
Individual housing that is usually located in the hillsides, use the more enviromentally damaging heating sources because most of them are informal settlements and energy poverty is a significant factor. Another reason is that gas piplines are not easily distributed to these areas.

The UNDP and the Italian Ministry of Environment, Land and Sea Protection in BiH conducted a feasibility study introducing several scenarios for the expansion and improvement of the DHS. One option was to expand the current system with natural gas as is. Another one was to expand the current system but transition to biomass in three adjacent satellite settlements, and the third option was to build a pipeline and bring hot water from the power plant in Kakanj. The study concluded that within current circumstances the option that would reduce most emission would be the second option - through partial use of biomass. The possibility of building a geothermal power plant in the southwest Municipality of llidza was also mentioned, as well as solar power potenital. Ilidza is one of the oldest inhabited settlements in the region, dating back to Neolithic, and well known for its thermal waters. Its geothermal energy is currently used for heating a few hotel facilites. The latest efforts in borehole drilling to evaluate geothermal water temperature for potential larger distribution was done in 2004, but not conducted entirely to the necessary depth. Together with solar power, the option of geothermal energy has been mentioned in the study but it has not been pursued further due to a lack of available data (UNDP, 2019).
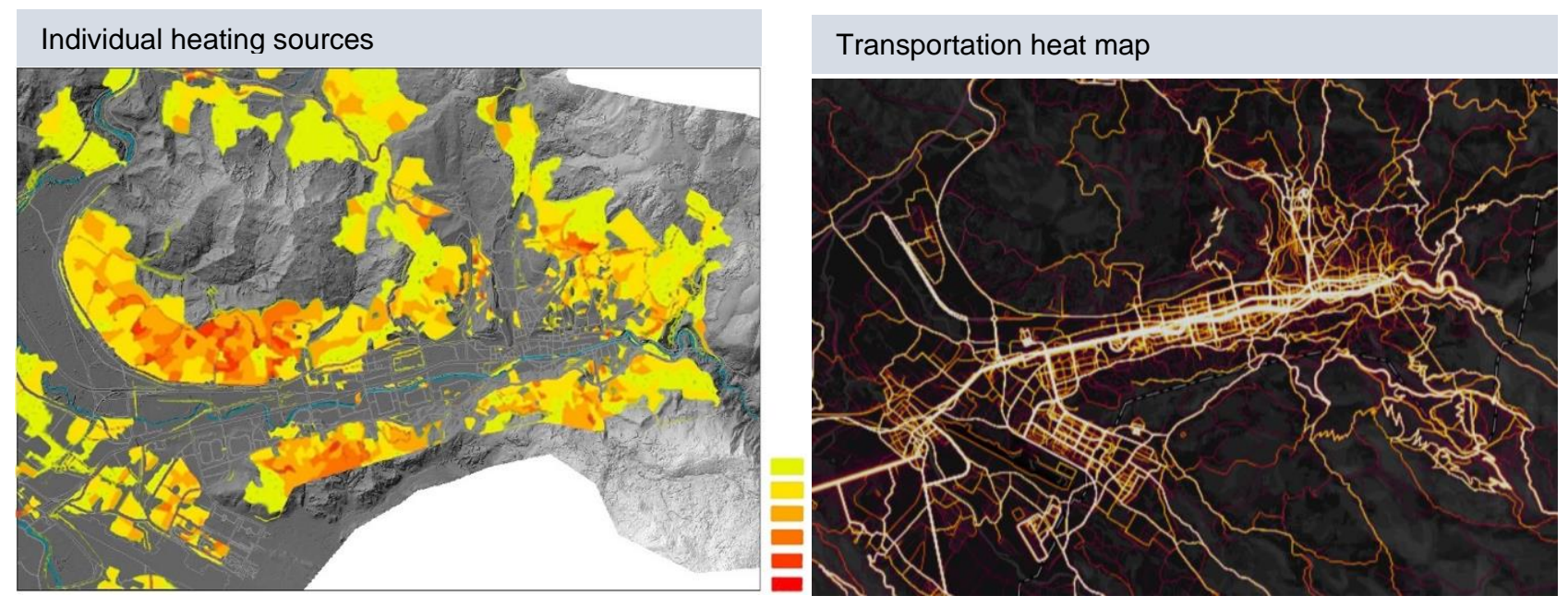

Figure7: a) Map displaying highest concentration of individual stoves b) Map displaying traffic pressure distribution Source: a) created based on Esri ArcGIS model with overlaying data derived from CS Planning Institue's comprehensive map of "Natural sources and conditions" b) STRAVA heat map

Bosnia and Herzegovina is one of the most forest rich countries in Europe. In 2016 USAID BiH published a report on the status and potential of biomass. Currently, there exist several small-scale biomass energy plants in the country. Wood biomass is the dominant untapped source with $56 \%$ of technical potential, followed by crop residue $35 \%$ and livestock residue $9 \%$ (USAID BiH, 2016). Although an environmentally more acceptable replacement for fossil fuels, burning wood smoke emits harmful particulate matter, especially when used in older stoves. With Sarajevo's topographically conditioned air circulation and lack thereof, this byproduct of combustion is a potential additional source of air pollution. There is still, however, potential of crop and livestock residue or wastewater treatment as a possible sources of biomass. 
Apart from traffic and heating, planning policy plays a significant role in air quality of Sarajevo. A study using Computational Fluid Dynamics in 2019 conducted air flow and particle simulation through parts of the city. The study suggests further construction of high-rise buildings needs to be carefully evaluated and strategically planned away from the recognized ventilation corridors in order to reduce pollution retention. (EBRD, 2019).

\subsection{Transportation}

The transportation system in Sarajevo follows the funnel shape of the valley with a predominant central artery that carries a tramway line and a parallel longitudinal street with a trolleybus line. As the funnel narrows the traffic congestion increases. However, the advantage of the orography and the current transit system is that most valley-based points are in a walking distance from transit, making Sarajevo a transit-oriented city. The public transit system, however, needs improvement and a distribution of additional railway lines, providing safer, well maintained transit vehicles with reduced waiting time. Motor vehicles on the streets often do not adhere to EU emission standards. The hillside areas in general are quite detached or connected with outdated public bus lines that present safety hazards especially during wintertime. In 2018 Sarajevo's old cable car line was reconstructed and opened to public. The line connects the city to mount Trebevic, so residents and tourists have a quick access to elevated area with fresh air and recreation.

As part of a PhD research on the linearity of Sarajevo's urban development, the importance of expansion of the transit network has been recognized. Moreover, a connection to the hillside developments through funiculars, inclined elevators and vertical park design has been suggested. Sarajevo already has a settlement with an operating inclined elevator. The settlement was constructed in the $1980 \mathrm{~s}$ in one of the steepest slopes in the city. Another proposed intervention is to limit traffic in the narrow part of the city, from Vijecnica to Skenderija, and establishing an Origin City Center Loop. Except for the residents with permit, motor vehicles would be allowed only in certain periods. Instead public transportation modes in the area would be multiplied and more frequent. (Tufek-Memisevic, T., 2018).

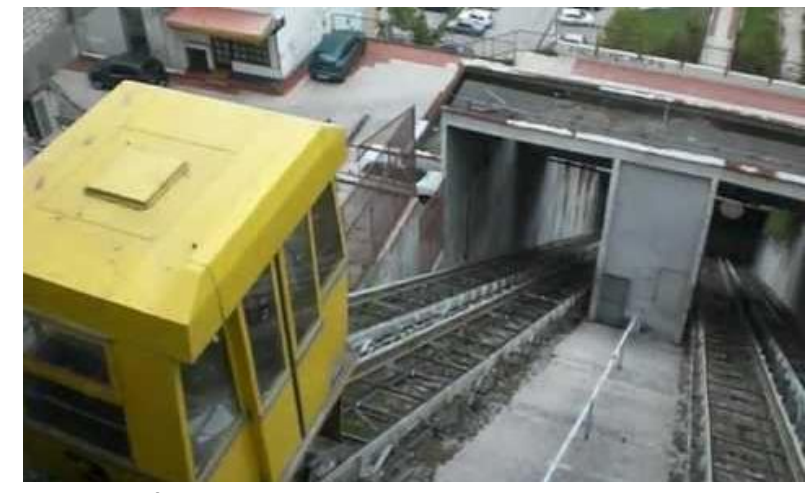

Figure8: a) inclined elevator in Ciglane, Sarajevo

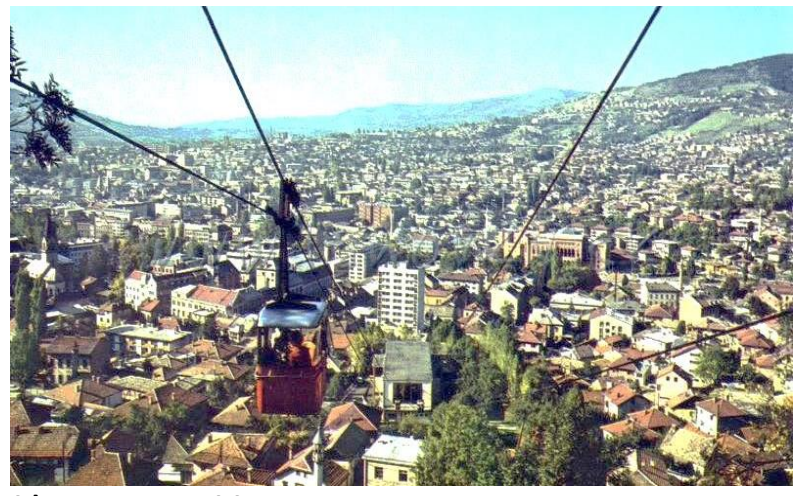

b) Sarajevo cable car

\section{Conclusion}

Cities surrounded by significant elevation changes deal with different types of temperature inversions. Combined with anthropogenic factors it affects air quality and causes pollution retention. This problem is particularly experienced in valley-based cities where such conditions can last for an extended period of time and are detrimental to the wellbeing of inhabitants. In order to achieve a sustainable urban development innovative modes of transit that are not dependent on burning fossil fuels need to be explored, especially in 
inclined areas. This research suggests that the post-oil future of valley-based cities like Sarajevo will significantly rely on the use of top and bottom types of cable propelled transit for commuters, not only as an attraction. CPT can be powered by electricity, gravity and even wastewater. Apart from low energy consumption these transit options have numerous other advantages such as low space requirement on the ground, rather quick installation and lower cost compared to other high-capacity public transport.

In a post-oil depleted future of cities that are topographically bound and influenced, in order to mitigate air pollution it is particularly important to investigate new sources of energy for heating, as the cooler seasons often tend to be more problematic in terms of air pollution.

The city of Sarajevo has existing potential to partly switch from fossil fueled energy sources to various types of biomass. Geothermal plants are an additional opportunity that together with solar energy needs to be further researched and pursued.

\section{References}

- Alshalalfah, B., Shalaby, A. and Dale, S. (2014). Experiences with Aerial Ropeway Transportation Systems in the Urban Environment. Journal of Urban Planning and Development, 140(1)

- Bassi, E. (2015). Divided Sarajevo: space management, urban landscape and spatial practices across the boundary. Europa Regional, 22.2014(3-4), 101-113

- Development Planning Institute of the Sarajevo Canton, (2016). Development Strategy of the Sarajevo Canton until 2020, Sarajevo

- EBRD \& Ministry of Phisical Planning, Construction and Environment Protection (2019), Zeleni akcioni plan Kantona Sarajevo. Studija o urbanim ventilacionim koridorima i uticaju visokih zgrada, Sarajevo Available at: https://mpz.ks.gov.ba/sites/mpz.ks.gov.ba/files/studija_o_urbanim_ventilacionim_kori dorima_i_uticaju_visokih_zgrada.pdf (2019), [Accessed May 16th 2020].

- CETEOR (2013) Akcioni plan za smanjenje za smanjenje čestičnih tvari u zraku, Sarajevo [online] Available at:

https://mpz.ks.gov.ba/sites/mpz.ks.gov.ba/files/Akcijski\%20plan\%20za\%20smanjenje\%20cesticn ih\%20tvari\%20-\%20za\%20WEB 0.pdf [Accessed May 16th 2020]

- REIC \& Ministry of Physical Planning, Construction and Environment Protection https://mpz.ks.gov.ba/sites/mpz.ks.gov.ba/files/brosuraupravljanje kvalitetom zraka u ks.pdf, Brošura Upravljanje kvalitetom zraka u Kantonu Sarajevo [Accessed May 16th 2020]

- Reimerink, L. (2017). Planners and the Pride Factor: The Case of the Electric Escalator in Medellín. Bulletin of Latin American Research, 37(2), pp.191-205.

- Schwab, E., (2018) Spatial Justice and Informal Settlements. Integral Urban Projects in the Comunas of Medellin, Emerald Publishing Limited

- Tsenkova, S., (2012.) Urban planning and informal cities in southeast europe. Journal of Architectural and Planning Research, 29(4), 292-305.

- Tufek-Memisevic ,T., (2018) Contemporary linear city development. A case of spatial interventions in Sarajevo, BiH, Unpublished PhD thesis, Politechnika Krakowska, Kraków

- UNDP (2019), Feasibility study on expanding and improving the district heating system in Sarajevo Canton Available at 
https://www.ba.undp.org/content/bosnia and herzegovina/en/home/library/environment ene rav/SazetakStudijeDHKS.html [Accessed April 25 2019].

- USAID Bosnia and Herzegovina, (2016) Izvještaj o trenutnom stanju i potencijalu u BiH za izgradnju kogeneracijskih postrojenja i elektrana na biomasu [pdf] Sarajevo: UNDP. Available at:

http://www.usaideia.ba/wp-content/uploads/2016/05/Izvjes\%CC\%8Ctaj-o-trenutnom-stanju-ipotencijalu-u-BiH-za-izgradnju-kogeneracijskih-postrojenja-i-elektrana-na-biomasu2.pdf?fbclid=IwAR1oxaLOxjYvgIrIlgO4Mzs8xonlqZAdxT4qgAAzU1p-HEnOluEH-W2p-pw

- www.iqair.com, (2020). 2019 World Air Quality Report. [online] IQAir. Available at: https://www.iqair.com/world-most-polluted-cities/world-air-quality-report-2019-en.pdf [Accessed Sept. 20th 2020]. 